"I am sorry that a well-respected body such as the Wolfson Foundation should have taken this step" says Major General Leslie Busk, director-general of the British Heart Foundation and chairman of the Association of Medical Research Charities. The association, all of whose members are required to sign a statement pledging their support for the use of animals in research, is planning to raise the issue with the Medical Research Council. Wolfson is not a member of the association and, with its current policy, would not be eligible for membership.

Other charity administrators say that Wolfson's policy could help to legitimize the campaigns of anti-vivisectionists and could be seen as implicit criticism of the efforts of laboratory researchers. "If you happen to be using animals, this is like a kick in the teeth", says one. "If all the charities followed the Wolfson's example, medical research would come to a standstill."

Such arguments are dismissed as overreaction by those campaigning for a significant reduction in the use of animals in research. "I would prefer to see the medical charities emphasizing the large amount of research they sponsor into alternatives to the use of animals, rather than making a big fuss out of this", says Michael Balls, chairman of the trustees of the Fund for the Replacement of Animals in Medical Experiments, and until recently professor of medical cell biology at the University of Nottingham.

Further support comes from Sir David Phillips, chairman of the Advisory Board for the Research Councils and a trustee of the foundation. "Wolfson's policy could be seen as an inducement to people to devise experiments which do not involve the use of animals, and almost everyone would agree that that is a good idea", he says.

David Dickson

\section{Research ministers approve Framework}

Munich. The council of research ministers of the European Communities (EC) last week approved the structure and the proposed ECU13.1 billion (US\$15.8 billion) budget for the EC's fourth framework programme, which will fund research from 1994 to 1998 . The positive response raises hope that the final text of the programme could be approved by the commission, council and parliament by the end of the year (see Nature 362, 778; 1993).

EC research commissioner Antonio Ruberti also announced preliminary plans to improve programme management by simplifying and decentralizing procedures. Details are not yet available, but one proposal is to establish regular deadlines for grant applications and to require for the first selection round a short summary of project proposals rather than the full 20-page application, as is now the case.

\title{
Japan adds supercomputers in one-time boost to budget
}

Tokyo. Research institutes of the Ministry of International Trade and Industry (MITI) and the Science and Technology Agency (STA) will receive supercomputers in a supplementary budget designed to help pull Japan out of recession (see Nature 362, 381; 1993). Many Japanese national universities will also benefit by getting much-needed Local Area Networks (LANs) to link on-campus computers. But an attempt by the science-related ministries and agencies and the ruling Liberal Democratic Party (LDP) to create a new budget category for these items and to crack the rigid ceiling on outlays for science has been defeated by the Ministry of Finance.

The supplementary budget, details of which are expected to be approved by the cabinet in the next few weeks, will include $¥ 25-30$ billion (US\$225-\$270 million) for 11 supercomputers and mini-supercomputers to be shared among six science-related ministries and agencies (see table). This is three or four times the number normally purchased each year by the government.

MITI will receive three, including one for its new National Institute of Advanced Interdisciplinary Research in Tsukuba which will be the centre for a large-scale government-industry project on nanotechnology. STA also gets three and the Ministry of Education, Science and Culture gets two for national universities or university-related institutes.

The computer for the National Cancer Center will form the central database for an online national network of imaging data on cancer patients. The supplementary budget is also said to include several billion yen to set up the network, part of the next ten-year cancer research programme to begin next year (see Nature 361, 672; 1993).

The Ministry of Agriculture, Forestry and Fisheries is expected to use its supercomputer for the rice genome project at the National Institute of Agrobiological Resources in Tsukuba, but the ministry has yet to reveal its plans. And the Ministry of Posts and Telecommunications will get a supercomputer for its single institute.

Supercomputers are not the only scientific elements in the supplementary budget. About $¥ 8$ billion will be set aside for on- campus LANs for 20-30 national universities, according to a government official involved in the negotiations with the Ministry of Finance. A few tens of billions of yen will also be spent on new buildings and facilities for the science-related ministries and agencies.

\section{Where the supercomputers will go}

$\begin{array}{lcl}\begin{array}{l}\text { Ministry/ } \\ \text { Agency } \\ \text { MITI }\end{array} & \text { Number } & \begin{array}{l}\text { Recipient } \\ \text { Tsukuba supercomputer centre (1); } \\ \text { National Institute for Advanced } \\ \text { Interdisciplinary Research (2) }\end{array} \\ \text { STA } & 3 & \begin{array}{l}\text { RIKEN (1) } \\ \text { Power Reactor and Nuclear Fuel } \\ \text { Development Corporation (1); } \\ \text { National Aerospace Laboratory (1) }\end{array} \\ \text { MESC } & 3 & \begin{array}{l}\text { MESC organizations } \\ \text { National Cancer Center } \\ \text { MHW }\end{array} \\ \text { MAFF } & 1 & \begin{array}{l}\text { MAFF institute in Tsukuba } \\ \text { Communications Research Laboratory }\end{array}\end{array}$

But the science-related ministries and agencies failed to classify such items as 'new social infrastructure' outside the present budgetary system. Despite the backing of the LDP, in particular Hiroshi Mitsuzuka, chairman of the ruling party's policy research council, the Ministry of Finance argued successfully that such changes require rewriting Japan's finance laws.

The LDP and science-related ministries and agencies are now trying to ensure that next year's budget includes provision for items such as a high-capacity national backbone network for linking computers in government institutes and universities. The ruling party is considering introducing a bill to allow national construction bonds to be used. Alternatively, it might use funds from the sale of government-held shares of Nippon Telegraph and Telephone, Japan Tobacco and JR railways as well as earnings from a proposed system of betting on football matches.

Although government officials are confident of somehow finding a way next year to pay for the national backbone network, they are sceptical of the LDP's ability to break through the ceiling on overall spending on science. The party's most likely recourse is a face-saving compromise with the Ministry of Finance that does not alter the status quo.

David Swinbanks 